\title{
Studies on Correlation and Path Analysis for Grain Yield and Quality Components in Foxtail Millet [Setaria italica (L.) Beauv.]
}

\author{
Ayesha Md"1 D. Ratna Babu ${ }^{2 *}$, J. Dayal Prasad Babu ${ }^{3}$ and V. Srinivasa Rao ${ }^{3}$ \\ ${ }^{1}$ Department of Genetics and Plant Breeding, ${ }^{3}$ Department of Statistics and Mathematics, \\ Agricultural College, Bapatla, India \\ ${ }^{2}$ Department of Genetics and Plant Breeding, APGC, Lam. Guntur, India \\ *Corresponding author
}

\section{Keywords}

Correlation, Foxtail millet genotypes, Path analysis

Article Info

Accepted:

17 March 2019

Available Online:

10 April 2019

\section{A B S T R A C T}

Correlation and path analysis were studied in 50 genotypes of foxtail millet for 13 characters during kharif 2017-18. The investigation revealed positive significant correlation of plant height, panicle length, number of productive tillers per plant, test weight and carbohydrate with grain yield per plant at phenotypic level. Path analysis studies revealed that panicle length, number of productive tillers per plant, test weight and carbohydrate had true relationship with grain yield per plant by establishing significant positive association and positive direct effect at phenotypic level. Considering the nature and magnitude of character associations and their direct and indirect effects, it can be inferred that panicle length, number of productive tillers per plant, test weight and carbohydrate could serve as important traits in any selection programme for developing high yielding foxtail millet genotypes.

\section{Introduction}

Foxtail millet is the second-most widely planted species of millet and the most important in East Asia. Foxtail millet has a relatively small stature, with plants of different accessions varying from 20 to 215 $\mathrm{cm}$ tall (Reddy et al., 2006).

It ranks second in the world's total production of millets and is an important staple food for millions of people in southern Europe and Asia. Foxtail millet is well adapted to temperate, sub-tropical and tropical Asia.
Foxtail millet is known for its drought tolerance and is an indispensable crop of vast rainfed areas in semi-arid regions in India. It is also grown in nutrient deficient soils and possesses tolerance to pests and diseases. Its grains are rich in protein, fibre, $\beta$ carotene, minerals viz., calcium, iron, potassium, magnesium, Zinc, antioxidants and vitamins (Rai, 2002).

It is essentially dry land crop on marginal and sub marginal lands although the world. It is grown to meet the domestic needs of rural people. It is usually cooked whole or made into meal or into beer. It can also make useful 
hay or silage. In addition foxtail millet is consumed as stiff porridge called sargati, or as leavened bread known as roti, after the dehulled grain has been milled into flour.

The aim of correlation studies is primarily to know the suitability of various characters for indirect selection because selection on any particular trait may bring about undesirable changes in other associated characters (Singh, 1988). The estimates of correlation coefficients mostly indicate the interrelationships of the characters whereas path analysis permits the understanding of the cause and effect of related characters (Wright, 1921). The path analysis reveals whether the association of characters with yield is due to their direct effect on yield or is a consequence of their indirect effects via other component characters. Thus the correlation and path analysis in combination, can give a better insight, into cause and effect relationship between different pairs of characters.

\section{Materials and Methods}

50 germplasm lines of foxtail millet obtained from ICRISAT, Hyderabad were evaluated at RARS, Lam, Guntur during kharif 2017-18. The germplasm was evaluated in Augmented Randomised Complete Block Design with three checks viz., korra local, Prasad and Suryanandi in each block. Each genotype was grown in a single row of $4 \mathrm{~m}$ length with a spacing of $22.5 \mathrm{~cm}$ between the rows and 10 $\mathrm{cm}$ between the plants. Data were collected on five randomly selected plants per entry for plant height, panicle length, no. of productive tillers per plant and grain yield per plant. While data on days to $50 \%$ flowering, days to maturity, test weight, protein, calcium, fat, carbohydrate, iron and phosphorus were recorded on plot basis. The data was subjected to statistical analysis and estimates of correlation coefficients were worked out as per Falconer (1964), direct and indirect effects of yield and quality traits on grain yield per plant were calculated as suggested by Dewey and Lu (1959).

\section{Results and Discussion}

The estimates of phenotypic correlation coefficient between all possible combinations have been presented in table 1. Plant height, panicle length, number of productive tillers per plant, test weight and carbohydrate were found to possess significant positive association with grain yield per plant. These results were in accordance with the findings of Sandhu et al., (1974), Dhagat et al., (1977), Sirisha et al., (2009), Prasanna et al., (2013a), Prasanna et al., (2013b) and Brunda et al., (2015). This suggests that selecting for these characters with significant positive correlation would improve the grain yield in foxtail millet.

Further highly significant and positive correlations were observed for days to $50 \%$ flowering with days to maturity, plant height with panicle length, test weight, number of productive tillers per plant and carbohydrate, panicle length with test weight, number of productive tillers per plant and carbohydrate, number of productive tillers per plant with test weight and carbohydrate, test weight with carbohydrate and protein at phenotypic level (Fig. 1). These findings are in conformity of reports given by Cill and Randhwa (1975), Dhagat et al., (1977), Tyagi et al., (2011), Prasanna et al., (2013a), Prasanna et al., (2013b) and Brunda et al., (2015).

The phenotypic Path coefficient analysis revealed that panicle length, number of productive tillers per plant, test weight and carbohydrate showed true relationship with grain yield per plant by establishing significant positive associations and positive direct effects (Table 2). 
Table.1 Phenotypic correlations among grain yield and yield contributing characters in foxtail millet [Setaria italica (L.) Beauv.]

\begin{tabular}{|c|c|c|c|c|c|c|c|c|c|c|c|c|c|}
\hline Character & $\begin{array}{c}\text { Days to } \\
50 \% \\
\text { flowering }\end{array}$ & $\begin{array}{c}\text { Plant } \\
\text { height }\end{array}$ & $\begin{array}{l}\text { Panicle } \\
\text { length }\end{array}$ & $\begin{array}{c}\text { No. of } \\
\text { productive } \\
\text { tillers } \\
\text { /plant }\end{array}$ & $\begin{array}{c}\text { Days to } \\
\text { maturity }\end{array}$ & Test wt & Protein & Fat & $\begin{array}{l}\text { Carbo- } \\
\text { hydrate }\end{array}$ & Iron & Phosphorus & Calcium & $\begin{array}{c}\text { Grain } \\
\text { yield/plant }\end{array}$ \\
\hline $\begin{array}{l}\text { Days to } 50 \% \\
\text { flowering }\end{array}$ & 1.0000 & 0.1288 & 0.0337 & -0.0489 & $0.9723 * *$ & 0.0126 & -0.0718 & -0.0073 & -0.1999 & -0.1636 & 0.0580 & -0.0334 & -0.0317 \\
\hline Plant height & & 1.0000 & $\begin{array}{c}0.5670 * \\
*\end{array}$ & $0.4346^{* *}$ & 0.1513 & $0.4972 * *$ & 0.2160 & 0.1944 & $0.2868 *$ & -0.2291 & 0.0042 & 0.1814 & $0.4405 * *$ \\
\hline Panicle length & & & 1.0000 & $0.6865 * *$ & 0.0986 & $0.7965^{* *}$ & 0.2395 & -0.1955 & $0.6597 * *$ & -0.1591 & -0.0441 & 0.0133 & $0.8307 * *$ \\
\hline $\begin{array}{l}\text { No of prod. } \\
\text { tillers/plant }\end{array}$ & & & & 1.0000 & -0.0402 & $0.7822 * *$ & 0.1940 & -0.1238 & $0.5316^{* *}$ & -0.2332 & -0.1640 & -0.0105 & $0.7494 * *$ \\
\hline Days to maturity & & & & & 1.0000 & 0.0595 & -0.0532 & -0.0256 & -0.1647 & -0.1531 & 0.0598 & -0.0934 & 0.0474 \\
\hline Test wt & & & & & & 1.0000 & $0.2707^{*}$ & -0.1642 & $0.6445^{* *}$ & -0.0870 & -0.1489 & 0.0224 & $0.8141 * *$ \\
\hline Protein & & & & & & & 1.0000 & 0.2441 & $0.3200^{*}$ & 0.2068 & -0.0131 & 0.1178 & 0.1938 \\
\hline Fat & & & & & & & & 1.0000 & -0.1350 & -0.1421 & 0.2542 & 0.2433 & -0.1581 \\
\hline Carbohydrate & & & & & & & & & 1.0000 & 0.0162 & 0.0718 & 0.1544 & $0.6303 * *$ \\
\hline Iron & & & & & & & & & & 1.0000 & 0.2044 & -0.1290 & -0.1898 \\
\hline Phosphorus & & & & & & & & & & & 1.0000 & 0.1319 & -0.1244 \\
\hline Calcium & & & & & & & & & & & & 1.0000 & -0.0413 \\
\hline Grain yield/plant & & & & & & & & & & & & & 1.0000 \\
\hline
\end{tabular}

* Significant at $5 \%$ level

** Significant at $1 \%$ level 
Table.2 Phenotypic direct and indirect effects of different traits on grain yield per plant in foxtail millet [Setaria italica (L.) Beauv.]

\begin{tabular}{|c|c|c|c|c|c|c|c|c|c|c|c|c|c|}
\hline Character & $\begin{array}{c}\text { Days to } \\
50 \% \\
\text { flowering }\end{array}$ & $\begin{array}{c}\text { Plant } \\
\text { height }\end{array}$ & $\begin{array}{l}\text { Panicle } \\
\text { length }\end{array}$ & $\begin{array}{l}\text { No. of } \\
\text { productive } \\
\text { tillers } \\
\text { /plant }\end{array}$ & $\begin{array}{l}\text { Days to } \\
\text { maturity }\end{array}$ & Test wt & Protein & Fat & $\begin{array}{l}\text { Carbo- } \\
\text { hydrate }\end{array}$ & Iron & Phosphorus & Calcium & $\begin{array}{c}\text { Grain } \\
\text { yield/plant }\end{array}$ \\
\hline $\begin{array}{l}\text { Days to } 50 \% \\
\text { flowering }\end{array}$ & -0.6914 & $\begin{array}{c}- \\
0.0095\end{array}$ & 0.0138 & -0.0121 & 0.6735 & 0.0032 & 0.0034 & -0.0004 & -0.0185 & 0.0078 & -0.0022 & 0.0006 & -0.0317 \\
\hline Plant height & -0.0891 & $\begin{array}{c}- \\
0.0736\end{array}$ & 0.2319 & 0.1071 & 0.1048 & 0.1253 & -0.0104 & 0.0101 & 0.0266 & 0.0110 & -0.0002 & -0.0031 & $0.4405 * *$ \\
\hline Panicle length & -0.0233 & 0.0417 & 0.4091 & 0.1692 & 0.0683 & 0.2007 & -0.0115 & -0.0102 & 0.0611 & 0.0076 & 0.0017 & -0.0002 & $0.8307 * *$ \\
\hline $\begin{array}{l}\text { No of prod. } \\
\text { tillers/plant }\end{array}$ & 0.0338 & 0.0320 & 0.2808 & 0.2465 & -0.0279 & 0.1971 & -0.0093 & -0.0064 & 0.0492 & 0.0112 & 0.0062 & 0.0002 & $0.7494 * *$ \\
\hline Days to maturity & -0.6723 & 0.0111 & 0.0403 & -0.0099 & 0.6927 & 0.0150 & 0.0026 & -0.0013 & -0.0152 & 0.0073 & -0.0023 & 0.0016 & 0.0474 \\
\hline Test wt & -0.0087 & 0.0366 & 0.3258 & 0.1928 & 0.0412 & 0.2520 & -0.0130 & -0.0085 & 0.0597 & 0.0042 & 0.0056 & -0.0004 & $0.8141 * *$ \\
\hline Protein & 0.0497 & $\begin{array}{c}- \\
0.0159\end{array}$ & 0.0980 & 0.0478 & -0.0368 & 0.0682 & -0.0480 & 0.0127 & 0.0296 & -0.0099 & 0.0005 & -0.0020 & 0.1938 \\
\hline Fat & 0.0050 & $\begin{array}{c}- \\
0.0143 \\
\end{array}$ & -0.0800 & -0.0305 & -0.0177 & -0.0414 & -0.0117 & 0.0519 & -0.0125 & 0.0068 & -0.0096 & -0.0042 & -0.1581 \\
\hline Carbohydrate & 0.1382 & $\begin{array}{c}- \\
0.0211\end{array}$ & 0.2698 & 0.1310 & -0.1141 & 0.1624 & -0.0154 & -0.0070 & 0.0926 & -0.0008 & -0.0027 & -0.0027 & $0.6303 * *$ \\
\hline Iron & 0.1131 & 0.0169 & -0.0651 & -0.0575 & -0.1061 & -0.0219 & -0.0099 & -0.0074 & 0.0015 & -0.0479 & -0.0077 & 0.0022 & -0.1898 \\
\hline Phosphorus & -0.0401 & $\stackrel{-}{0.0003}$ & -0.0180 & -0.0404 & 0.0415 & -0.0375 & 0.0006 & 0.0132 & 0.0066 & -0.0098 & -0.0378 & -0.0023 & -0.1244 \\
\hline Calcium & 0.0231 & 0.0133 & 0.0054 & -0.0026 & -0.0647 & 0.0056 & -0.0057 & 0.0126 & 0.0143 & 0.0062 & -0.0050 & -0.0173 & -0.0413 \\
\hline
\end{tabular}

* Significant at $5 \%$ level ** Significant at $1 \%$ level Residual Effect $=0.4390$ 
Fig.1 Pictorial representation of phenotypic correlations among the studied traits in foxtail millet [Setaria italica (L.) Beauv.]

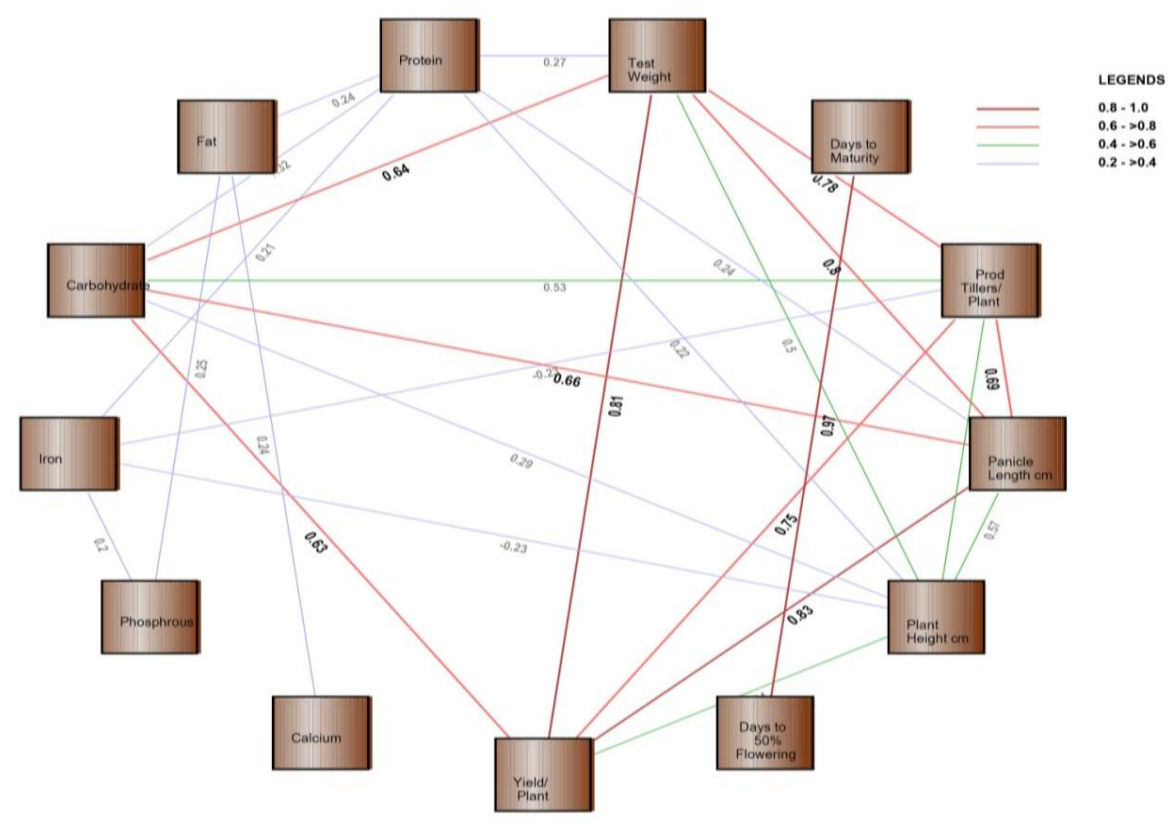

Fig.2 Phenotypic path diagram showing direct and indirect effects of yield and quality components on grain yield per plant in foxtail millet [Setaria italica (L.) Beauv.]

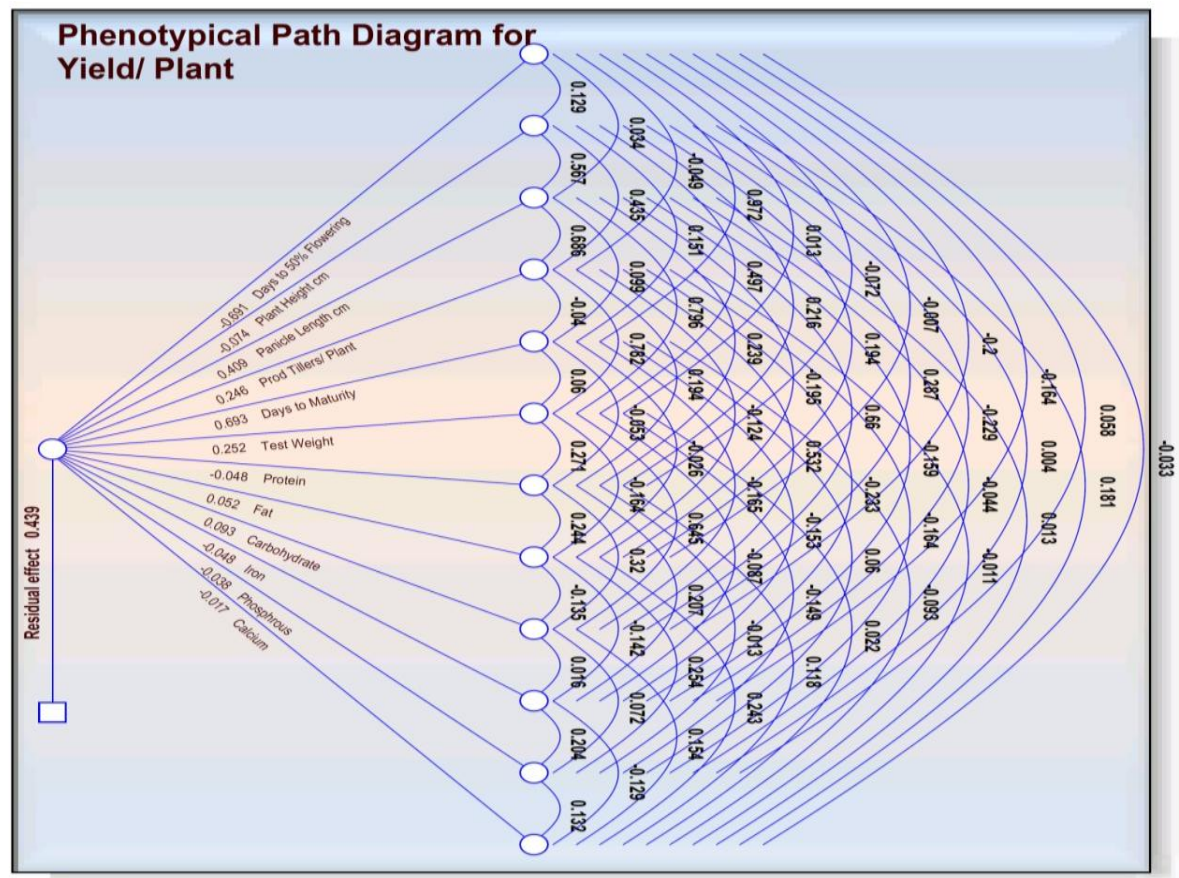

These results were in accordance with the findings of Nagarajan and Prasad (1980), Sirisha et al., (2009), Tyagi et al., (2011),
Prasanna et al., (2013a), Prasanna et al., (2013b) Brunda et al., (2015) and Ashok et al., (2016) for panicle length, number of 
productive tillers per plant and test weight, while similar observation for the carbohydrate was indicated by Kavya (2016). The residual effect was also low, validating the accuracy of the results obtained in path coefficient analysis. Hence, these traits are to be considered during selection of genotypes for improving the dependent variable i.e. grain yield per plant.

High and positive direct effect of panicle length on yield was slightly encountered by its negative indirect effect via days to $50 \%$ flowering, plant height, protein, fat and calcium. On the other hand, low and positive direct effect of number of productive tillers per plant was complemented by its high indirect effect through panicle length followed by test weight to produce a significant and positive correlation with yield (Fig. 2).

Considering the nature and magnitude of character associations and their direct and indirect effects, it can be inferred that panicle length, number of productive tillers per plant, test weight and carbohydrate could serve as important traits in any selection programme for developing high yielding foxtail millet varieties.

\section{References}

Ashok, S., Patro, T.S.S.K., Jyothsna, S and Divya, M. 2016. Studies on genetic parameters, correlation and path analysis for grain yield and its components in foxtail millet (Setaria italica). Progressive Research. 11(3): 300-303.

Brunda, S.M., Kamatar, M.Y., Hundekar, R and Naveenkumar, K.L. 2015. Studies on correlation and path analysis in foxtail millet genotypes [Setaria italica (L.) P.B.]. Green Farming. 6(5): 966-969.
Cill, A.S and Randhawa, A.S. 1975. Heritable variation and inter relationship in foxtail millet [Setaria italica (L.) P. Beauv.]. Madras Agricultural Journal. 62 (5): 253-258.

Dewey, O.R and Lu, K.H. 1959. A correlation and path coefficient analysis of component of crested wheat grass seed production. Agronomy Journal. 57: 515-518.

Dhagat, N.K., Goswani, U and Narsinghani, V.G. 1977. Character correlations and selection indices in Italian millet. Indian Journal of Agricultural Sciences. 47(12): 599-603.

Falconer, D.S. 1964. An Introduction to Quantitative Genetics. Oliver and Boyd, Edinburgh, London. pp. 312324.

Kavya, P. 2016. Genetic divergence for morphological and nutritional traits in italian millet (Setaria italica (L.) P. Beauv.) germplasm. M.Sc.(Ag.) thesis, Professor Jayashankar Telangana State Agricultural University, Hyderabad.

Nagarajan, K and Prasad, M.N. 1980. Studies on correlation, path, variability in foxtail millet [Setaria italica (L.) Beauv.]. Madras Agricultural Journal. 67(4): 134-135.

Prasanna, P.L., Murthy, J.S.V.S., Kumar, P.V.R and Rao, S.V. 2013a. Studies on correlation and path analysis in Indian genotypes of Italian millet [Setaria italica (L.) Beauv.]. World Research Journal of Plant Breeding. 1(2): 140-147.

Prasanna, P.L., Murthy, J.S.V.S., Kumar, P.V.R and Rao, S.V. 2013b. Studies on correlation and path analysis in exotic genotypes of Italian millet [Setaria italica (L.) Beauv.]. Electronic Journal of Plant Breeding. 4(1): 1080-1085.

Rai, M. 2002. Nutritive cereals. (in) Survey of Indian Agriculture, The Hindu, 
Chennai, Tamil Nadu, India, pp. 5962.

Reddy, V., Upadhyaya and Gowda, C. 2006. Characterization of world's foxtail millet germplasm collections for morphological traits. Journal of SAT Agricultural Research 2: 1-3.

Sandhu, T.S., Arora, B.S and Singh, Y. 1974. Interrelationships between yield and yield components in foxtail millet. Indian Journal of Agricultural Sciences. 44(9): 563-566.

Singh P. 1998. Cotton Breeding, Kalyani Publishers, New Delhi, pp. 191-211.

Sirisha, A.B.M., Rao, C.P., Kumar, P.V.R and
Rao, V.S. 2009. Variability, character association and path coefficient analysis in italian millet [Setaria italica (L.) Beauv.]. The Andhra Agricultural Journal. 56(4): 441-446.

Tyagi, V., Ramesh, B., Kumar, D and Sukrampal. 2011. Genetic architecture of yield contributing traits in foxtail millet (Setaria italica). Current Advances in Agricultural Sciences. 3(1): 29-32.

Wright, S. 1921. Correlation and causation. Journal of Agricultural Research, 20: 557-585.

\section{How to cite this article:}

Ayesha Md, D. Ratna Babu, J. Dayal Prasad Babu and Srinivasa Rao, V. 2019. Studies on Correlation and Path Analysis for Grain Yield and Quality Components in Foxtail Millet [Setaria italica (L.) Beauv.]. Int.J.Curr.Microbiol.App.Sci. 8(04): 2173-2179.

doi: https://doi.org/10.20546/ijcmas.2019.804.255 